\title{
Human Immunodeficiency Virus Infection Down-Regulates HLA Class II Expression and Induces Differentiation in Promonocytic U937 Cells
}

\author{
A. J. Chantal Petit, Fokke G. Terpstra, and Frank Miedema \\ Central Laboratory of the Netherlands Red Cross Blood Transfusion Service and Laboratory for Experimental and Clinical Immunology, \\ University of Amsterdam, Amsterdam, The Netherlands
}

\begin{abstract}
We studied the effect of human immunodeficiency virus (HIV) infection on the surface-marker expression of the human promonocytic cell line U937. U937 cells persistently produced HIV as detected by reverse transcriptase activity in culture supernatant. Expression of HLA class II antigens on U937/HIV cells was decreased 2- to 10-fold, depending on the Mab used. Class II expression of U937/HIV cells increased approximately twofold by treatment with r-interferon- $\gamma$. Whereas noninfected $U 937$ cells expressed moderate amounts of lymphocyte function-associated antigen-1 (LFA-1) (CD11a) and minimal amounts of the C3bi receptor (CD11b) and p150/95 (CD11c), U937/HIV cells expressed moderate amounts of $\mathrm{C} 3 \mathrm{bi}$ receptor and p150/ 95 and showed elevated expression of LFA-1 $\alpha$ (CD11a) and $-\beta$ (CD18) chains. Expression of these adhesion molecules resulted in strongly enhanced phorbolester-induced aggregation of U937/ HIV cells compared with the noninfected U937 cells. In addition, almost all U937/HIV cells, but not noninfected U937 cells, intensely stained for cytoplasmic nonspecific esterase activity. The effects of HIV infection on U937 cells strikingly resemble the effects of differentiation-inducing agents, such as PMA and DMSO, on the U937 phenotype. Our finding suggests that HIV infection, apart from down regulating class II expression, induces differentiation of $\mathbf{U} 937$ cells.
\end{abstract}

\section{Introduction}

It is now well established that human monocytes/macrophages and follicular dendritic cells can be infected with the human immunodeficiency virus (HIV) ${ }^{1}(1-3)$. HIV is cytopathic for $\mathrm{T}^{+}$ cells that express large amounts of CD4 but not for monocytes

Address reprint requests to Dr. F. Miedema, C/o Publication Secretariat, Central Laboratory of the Netherlands Red Cross Blood Transfusion Service, P.O. Box 9406, 1006 AK, Amsterdam, The Netherlands.

Received for publication 23 January 1987.

1. Abbreviations used in this paper: APC, antigen-presenting cell; FcR, Fc receptor; FITC, fluorescein isothiocyanate; HIV, human immunodeficiency virus; IMDM, Iscove's modified Dulbecco's medium; LFA1, lymphocyte-function-associated antigen-1; Mab, monoclonal antibody; PMA, phorbol 12-myristate 13-acetate; r-interferon- $\gamma$, recombinant interferon- $\gamma, \mathrm{RT}$, reverse transcriptase; $\mathrm{TCID}_{50}$, tissue culture infectious dose 50 .

J. Clin. Invest.

(c) The American Society for Clinical Investigation, Inc.

0021-9738/87/06/1883/07 $\$ 1.00$

Volume 79, June 1987, 1883-1889 or EBV-transformed B cell lines that express minimal amounts of CD4 antigen $(4,5)$. Hence, monocytic cells may well serve as a reservoir in virus dissemination and persistence, in analogy to the lentivirus model $(6,7)$. On the other hand, the HIV infection of monocytic cells, although not directly lethal, may have profound effects on the functional properties of the monocytic cells. Since monocytes and follicular dendritic cells have a crucial role as antigen-presenting cells (APC) in both the cellular and humoral immune response, this may explain immune abnormalities observed in HIV-infected individuals with normal $\mathrm{CD}^{+}$ $T$ cell numbers (8). Abnormalities in monocyte chemotaxis (9) and accessory cell functions for $T$ cell proliferation (10) have been reported in acquired immunodeficiency syndrome (AIDS) and ARC. Moreover, Heagy et al. (11) and Belsito et al. (12) demonstrated that monocytes and Langerhans cells, the epidermal APC, of AIDS patients, expressed decreased amounts of HLA class II antigens. These findings may imply that HIV infection of monocytic cells may influence membrane-antigen expression and functional capacities of APC.

Here, we studied the effects of HIV infection of the promonocytic cell line U937. Phenotypic analyses with monoclonal antibodies (Mab) against myeloid differentiation antigens revealed that $\mathrm{HIV}$ infection induced expression of $\mathrm{CD} 11 \mathrm{~b}$ (C3bi receptor) and CD11c (p150/95)-adhesion molecules and enhanced the expression of lymphocyte function-associated antigen-1 (LFA-1) (CD1 1a). In contrast, class II antigen expression was down regulated on HIV-infected U937 cells. Taken together, our findings strongly suggest $\mathrm{HIV}$-induced differentiation of U937 cells to a more mature monocytic phenotype.

\section{Methods}

Cells. The cell lines H9 and H9/HTLV-III-B (13) and the human monocytic cell-lines U937 and U937/HIV were grown in Iscove's modified Dulbecco's medium (IMDM) supplemented with $10 \%$ fetal calf serum (FCS) and antibiotics. The cell lines were routinely monitored for mycoplasm infection and repeatedly shown to be negative.

Virus and virus transmission. HIV was propagated and isolated from the H9 cell line infected with the HIV strain designated HTLV-III-B (13). Supernatant from the cell line was titrated on $\mathrm{H} 9$ cells and shown to have a $\operatorname{TCID}_{50}>10^{5}(14)$. For infection of U937 cell cultures, pelleted U937 cells $\left(10^{7}\right)$ were incubated for $1 \mathrm{~h}$ at $37^{\circ} \mathrm{C}$ with $1 \mathrm{ml}$ of a virus inoculum with a $\operatorname{TCID}_{50}>10^{5}$ in the presence of $25 \mu \mathrm{g} / \mathrm{ml}$ polybrene. The cells were then seeded in $5-\mathrm{ml}$ cultures $\left(10^{6} / \mathrm{ml}\right)$ in IMDM, $10 \%$ FCS.

Reverse transcriptase ( $R T$ ) assay. Reverse transcriptase activity was determined in polyethylene glycol $(10 \%)$ precipitates of cell culture supernatants as described before (15) with minor modification.

Detection of viral antigen expression by indirect immunoperoxidase staining. Indirect immunoperoxidase staining with a human anti-HIV 

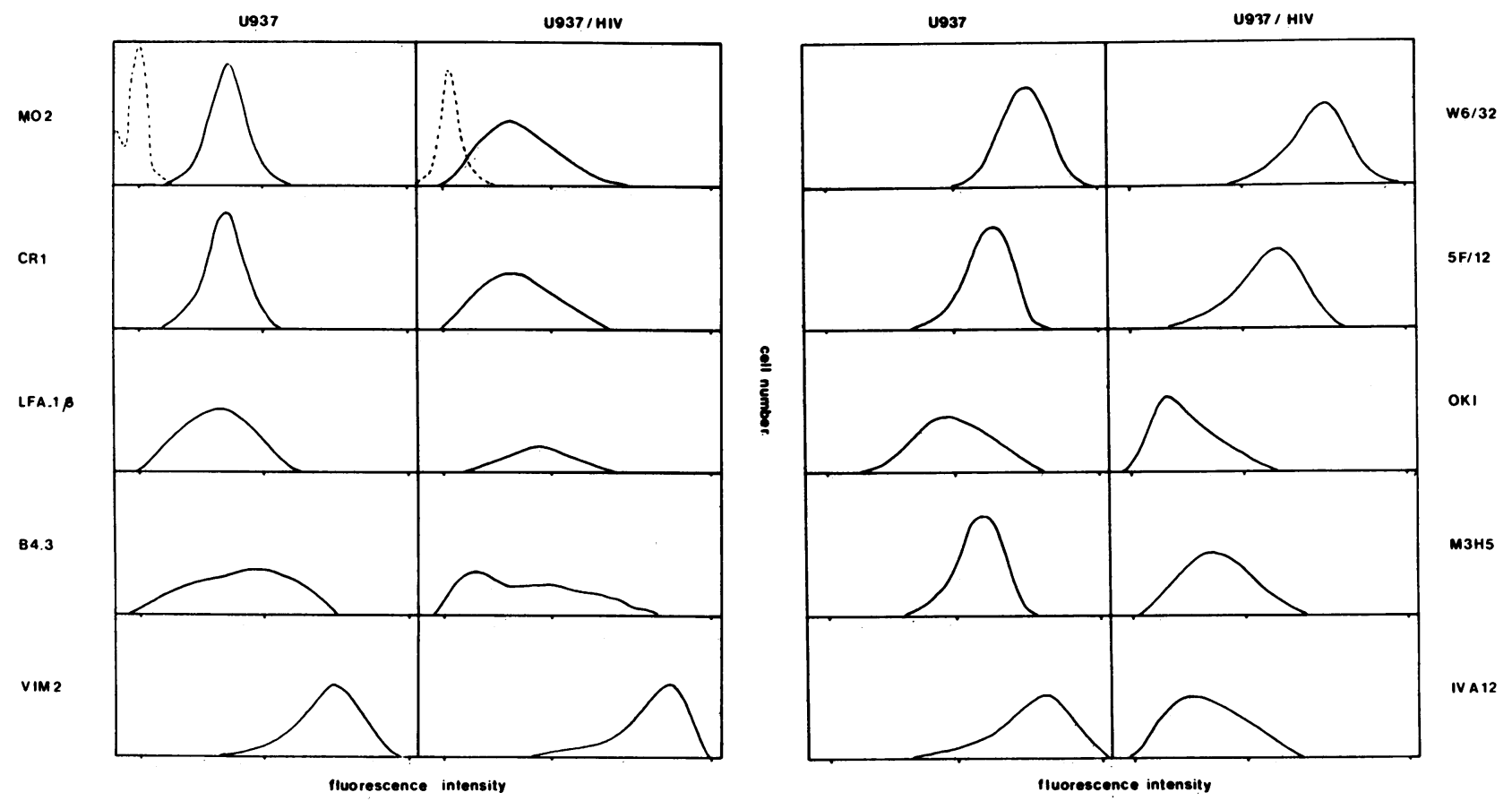

Figure 1. Phenotypic analysis of noninfected U937 cells and HIV-infected U937 cells, designated U937/HIV. The cells were indirectly stained with MO2 (CD14); J3B11 (CD35) (CR1); CLB-LFA-1/1 ( $\beta$ ) (CD18); B4.3; VIM2; W6/32, and 5F12 anti-class I framework Mab; and OKI, M3H5 and IV A12 anti-class-II Mab. As control, CLB-T8/1 (CD8) was used (dotted lines). Fluorescence intensity is expressed on a log scale.

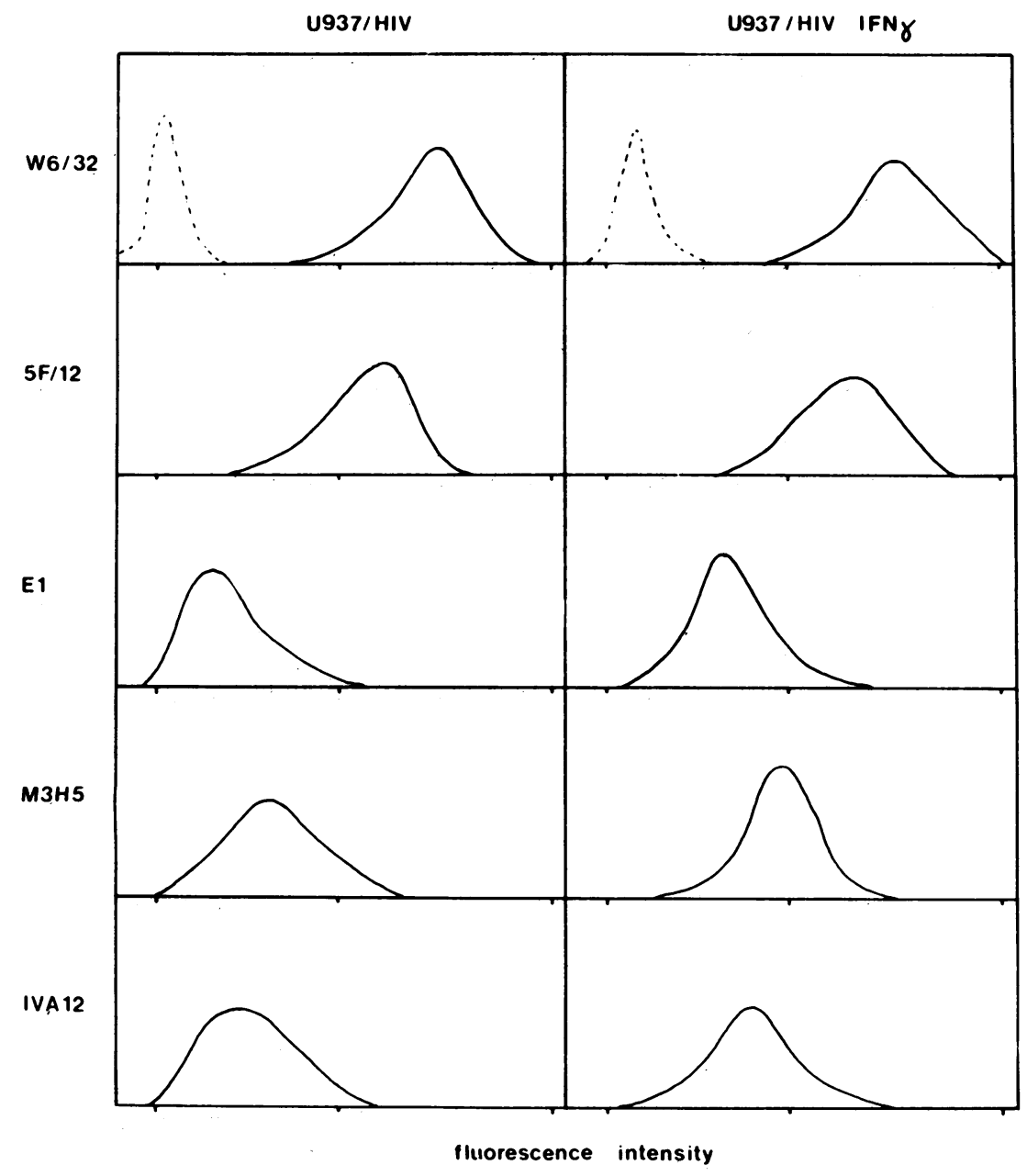

Figure 2. Cytofluorographic analysis of U937/ HIV cells and r-interferon- $\gamma$-treated U937/HIV cells stained with anti-class I (W6/32 and 5F12) and anti-class II (E1, M3H5, and IV A12) Mab.

1884 A. J. C. Petit, F. G. Terpstra, and F. Miedema 


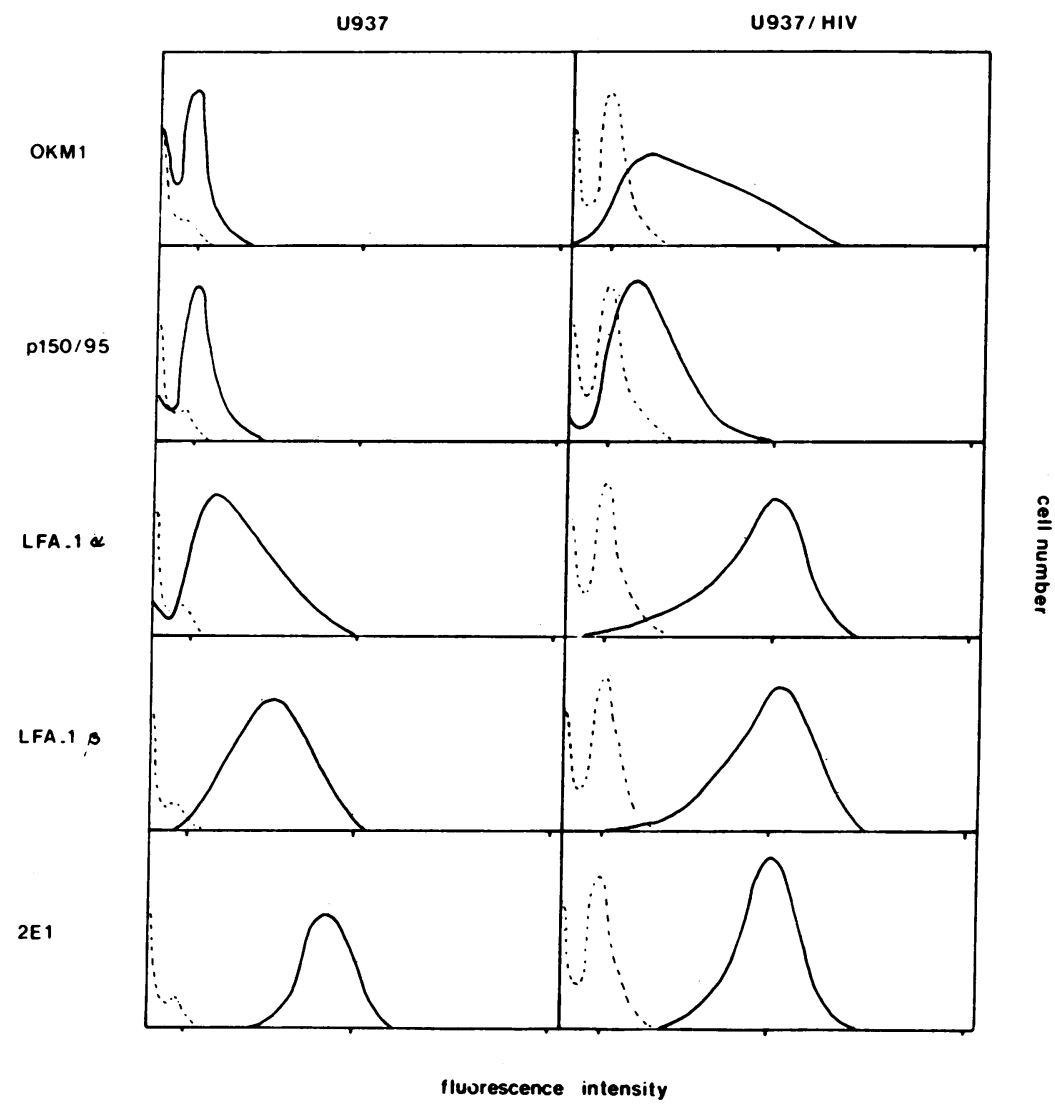

Figure 3: Expression of CD1 lb (OKM1), p150/95, LFA- $1 \alpha$, and the common $\beta$-chain (CD18) on U937 and $\mathrm{U} 937 / \mathrm{HIV}$ cells. Included are $2 \mathrm{E} 1$ (FcRII) and, as control, CLB-T8/1 (CD8) (dotted lines). serum-containing antibodies against all major viral proteins (p24, gp41, and pg160) on immunoblots and biotinylated anti-human IgG antibodies and preformed avidin-biotin complex-coupled peroxidase was performed on unfixed cytospin centrifuge preparations as described (16).

Detection of nonspecific esterase in U937 and U937/HIV cells. To detect cytoplasmic nonspecific esterase ( $\alpha$-naphthyl esterase) activity in U937 and U927/HIV cells, cytospin centrifuge preparations were fixed and stained by routine methods (17).

Indirect immunofluorescence assay. The U937 and U937/HIV cells were incubated with Mab, soluted in PBS containing 0.5\% BSA and azide, for $30 \mathrm{~min}$ and then washed with PBS, $0.5 \%$ BSA, azide. Then, they were incubated with FITC-labeled goat anti-mouse antibodies for 30 min and finally washed three times with PBS $0.5 \%$ BSA, azide. Cell surface-marker analysis was performed on a Coulter Epics-C cytofluorometer (Coulter Electronics, Hialeah, FL). The following Mab were used: B4.3 (18), VIM2 (19) and CLB-mon/1 (MO2-like) (CD14) against myeloid differentiation antigens; 2El against the FcRII (p40) on U937 (20), J3B11 (CD35) against complement receptor 1 (CR1), both obtained through the Third Workshop on Leucocyte Differentiation Antigens; anti-HLA class I monomorphic Mab HB.95 (W6/32) (21) and 5F12 (produced by R. A. W. van Lier, this Institute); anti-HLA class-II Mab OKI (Ortho Pharmaceutical Corp., Raritan, NJ) IV A12 (22), R3E2, M3H5, E1, CLB-HLA-DR2 (all four described elsewhere) ${ }^{2} \mathrm{OKM} 1$, directed against the $\alpha$-chain of the C3bi receptor (Ortho Pharmaceutical) (23); anti-Leu M5 Mab, previously designated S-HCL3 and directed against the $\alpha$-chain of p150/95, obtained from Becton Dickinson (Mountain View, CA) (24); CLB-LFA-1/1 (25) and TS1/18 (26), both directed against the $\beta$-chain of the LFA-1 antigen (CD18); SPV-L1 and

2. de Rie, M. A., P. Kabel, R. W. Sauerwein, R. A. W. van Lier, A. E. G. Kr. von dem Borne, C. J. M. Melief, and F. Miedema. Anti-HLA class II monoclonal antibodies inhibit polyclonal B cell differentiation in vitro at the accessory cell level. Eur. J. Immunol. In press.
SPV-L7, directed against the $\alpha$-chain of the LFA-1 antigen (CD11a) (27); CLB-T8/1, directed against the T8 antigen (CD8), was used as a negative control. To compare antigen expression of U937 and U937/ HIV cells, the mean channel of fluorescence was converted from logarithmic to linear values with a log-linear calibration curve.

Incubation of U937/HIV with r-interferon- $\gamma$. Recombinant interferon$\gamma$, kindly provided by Dr. C. J. Lucas, was added in a concentration of $50 \mathrm{U}$ per $1 \times 10^{6} \mathrm{U}$ 937/HIV cells in a volume of $1 \mathrm{ml} \mathrm{IMDM,} \mathrm{20 \%}$ FCS, antibiotics. After $2 \mathrm{~d}$ of culture in flat-bottomed 24-well plates (Costar Data Packaging, Cambridge, MA), the U937/HIV cells were harvested and cytofluorescence analysis was performed.

PMA-induced aggregation of U937 and U937/HIV cells. An aggregation assay was carried out as described (28). Briefly, $2 \times 10^{5}$ U937 or U937/HIV celis in $100 \mu \mathrm{ll}$ IMDM, $10 \%$ FCS, antibiotics and $50 \mu \mathrm{l}$ of $200 \mathrm{ng} / \mathrm{ml}$ phorbol 12-myristate 13-acetate (PMA) were added to wells of flat-bottomed 96-well microtest plates. The cells were incubated at $37^{\circ} \mathrm{C}$ and aggregation was scored after 45 and $90 \mathrm{~min}$ through an inverted microscope.

\section{Results}

Productive infection of the U937 cell line with HIV. After inoculation of U937 with HIV, RT activity measured in culture supernatants increased markedly after $3 \mathrm{wk}$, indicating virus production by the cell line, and remained high thereafter (range $10^{4}-2 \times 10^{5} \mathrm{cpm}$ ) (data not shown). At least $80 \%$ of the U937/ HIV cells were shown to be infected by HIV with indirect immunoperoxidase staining with human anti-HIV antibodies on cytocentrifuge preparations (not shown). No changes in growth rate or morphology were observed in the U937 cells after infection with HIV.

$H L A$ class-II antigens are down-regulated on U937/HIV cells. After inoculation of U937 cells with HIV, the HLA class 


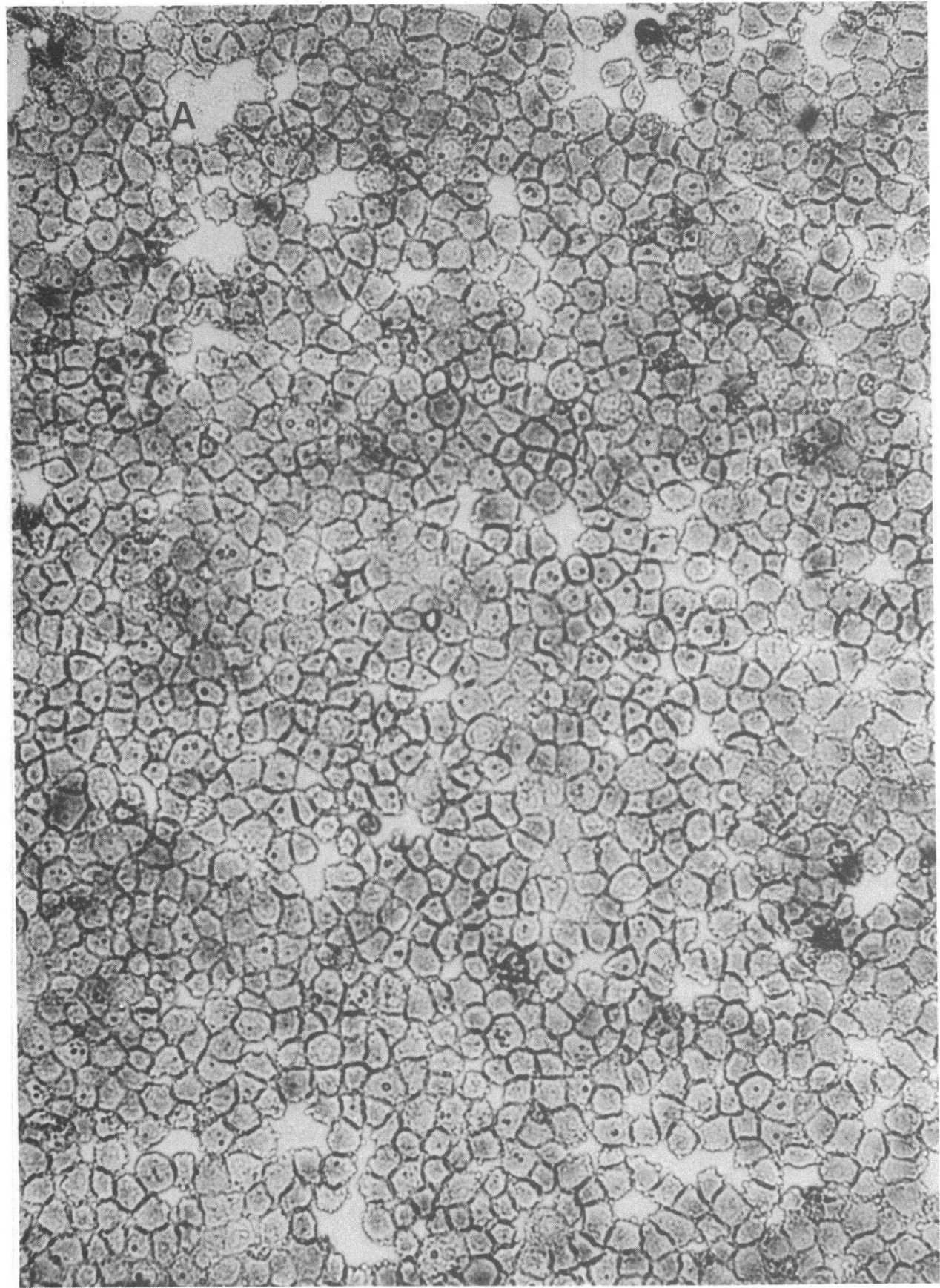

Figure 4. Nonspecific esterase activity in U937 $(A)$ and U937/HIV $(B)$ cytocentrifuge preparations $(\times 220)$.
II antigen expression was studied with a panel of six anti-class II Mab. The class II antigen expression of U937/HIV was down regulated to 7 to $50 \%$ of the expression on noninfected U937 cells, depending on the Mab used. The expression of class II antigens detected by OKI, M3H5, and IVA12 Mab was decreased to 27,25 , and $7 \%$, respectively, of the expression on noninfected U937 cells (Fig. 1). For comparison, expression of HLA class I antigens was studied with two Mab and found unchanged or slightly elevated (Fig. 1). The reproducibility of the down regulation of class II antigen expression was demonstrated by repeated HIV infection of the parental U937 cell line. Class II antigen expression was persistently decreased, starting 2 wk after inoculation with HIV (data not shown).
No significant difference in the expression of CD14, CR1 (CD35), and the antigen recognized by VIM2 was observed between U937 and U937/HIV. However, a significant decrease in expression of the antigen recognized by B4.3 and an increase in LFA-1 expression was observed after infection with HIV.

r-Interferon- $\gamma$ reinduces class-II expression on $U 937 / H I V$. It has been reported that interferon- $\gamma$ enhances the expression of class-II antigens on myeloid-monocytic cells $(29,30)$. To investigate whether the down regulation of class II expression by HIV infection was reversible, U937/HIV cells were stimulated with r-interferon- $\gamma$. After $48 \mathrm{~h}$ of incubation with r-interferon$\gamma\left(50 \mathrm{U} / 1 \times 10^{6}\right.$ cells $)$, the expression of MHC class II antigens increased approximately twofold (Fig. 2). The expression of class I antigens was also slightly increased by $r$-interferon- $\gamma$ treatment. 


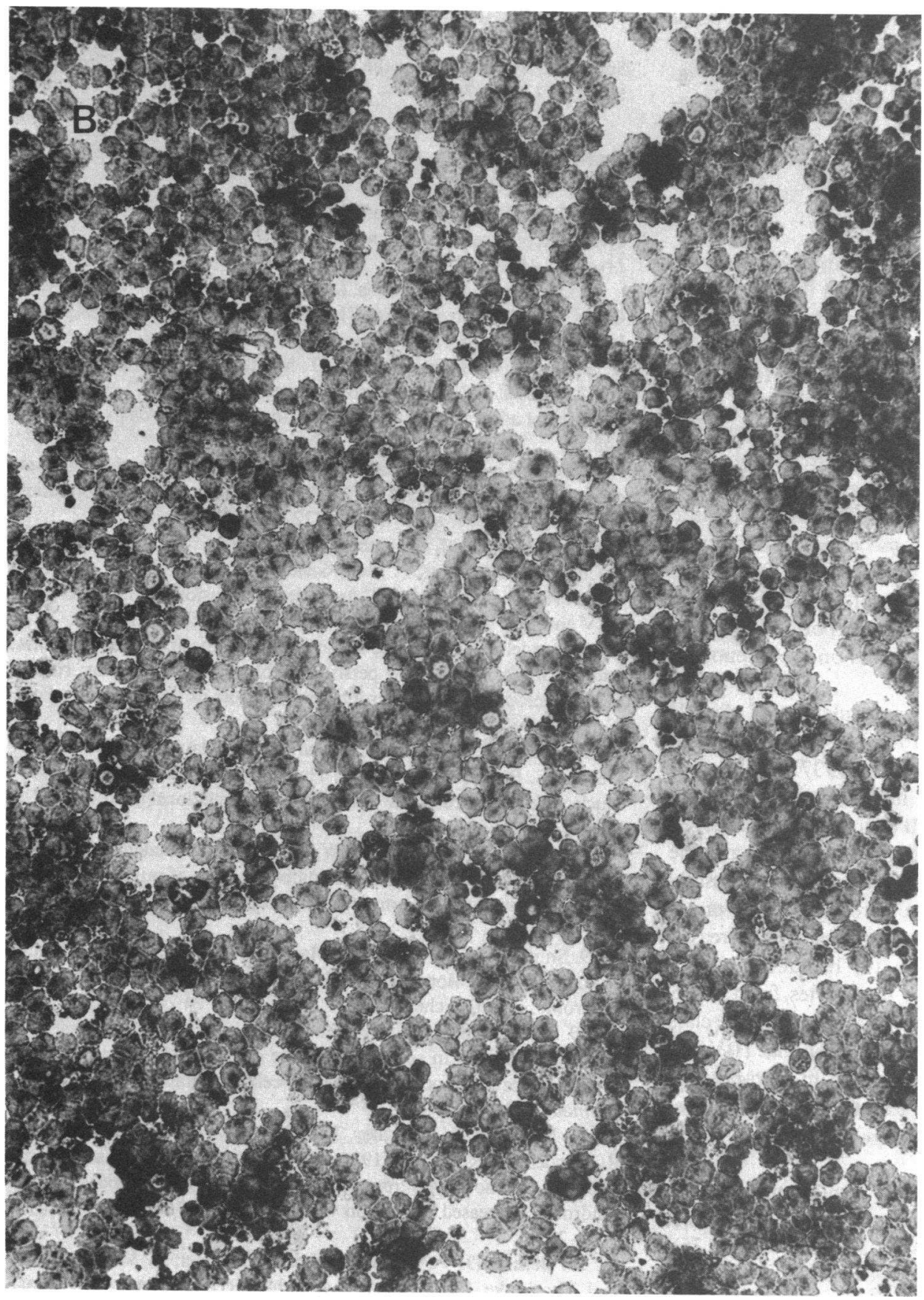

Figure 4 (Continued)

$H I V$ infection induces expression of CD11b (C3bi receptor) and CD11c (p150/95) adhesion molecules on U937 cells. U937 is a promonocytic cell line that expresses moderate amounts of CD11a (LFA-1) and expresses very little CD11b (detected by OKM1/MO1 Mab) and CD11c (p150/95) molecules (26-28, $31)$. Since we observed an elevated expression of LFA- $1 \beta$-chain on U937/HIV (Fig. 1), the effect of HIV infection on the expression of other members of this family of proteins involved in cell-surface adhesion reactions, i.e., CD11b, CD11c, was studied. A summary of data obtained in several experiments is shown in Fig. 3. The expression of LFA-1 $\beta$-chain, detected by two different Mab (data are shown for CLB-LFA-1/1), and the LFA$1 \alpha$-chain is clearly elevated, both fourfold. HIV-infected U937 cells expressed moderate amounts of CD11b and CD11c.
Expression of FcyRII (Mab 2E1) did not change upon infection (Fig. 3). Next, it is investigated whether the enhanced expression of these adhesion molecules would cause increased aggregation of U937/HIV cells compared with the noninfected U937 cells. After stimulation with PMA (70 ng/ml) for 45 or $90 \mathrm{~min}$, U937 cells did not aggregate ( $<10 \%$ of cells aggregated), like has been described (28). In contrast, complete aggregation (90-100\% of cells aggregated) was observed with U937/HIV cells after $30 \mathrm{~min}$.

Detection of nonspecific esterase in U937/HIV. The effect of HIV infection on the U937 phenotype resembles the effect of differentiation-inducing agents, such as PMA and DMSO (18, $28,31,32$ ). To obtain additional evidence for HIV-induced differentiation in U937, histochemical analysis of cytoplasmic 
nonspecific esterase activity was performed (33). Noninfected U937 cells stained very weakly for nonspecific esterase, whereas almost all HIV-infected U937 cells were strongly positive (Fig. 4). Taken together, these results are compatible with differentiation induction by HIV in U937 cells.

\section{Discussion}

In this study, we describe the effects of HIV infection on promonocytic U937 cells. The data strongly suggest that upon HIV infection U937 cells differentiate to more mature monocytic cells. The infected cells expressed lowered amounts of the antigen recognized by B4.3 (18) and elevated amounts of LFA-1- $\beta$ and $-\alpha$. Moreover, expression of CD11b (C3bi receptor) and CD11c (p150/95) was induced on these cells. The elevated expression of adhesion molecules was further demonstrated by enhanced aggregation of U937/HIV cells upon stimulation with PMA. Furthermore, differentiation of U937/HIV cells to more mature monocytes was confirmed by the intense expression of cytoplasmic nonspecific esterase, whereas noninfected U937 cells lacked esterase activity. All these effects of HIV infection on U937 cells are in agreement with findings reported before on the effects of differentiation-inducing agents on the phenotype of U937 cells $(18,28,31-33)$.

It is as yet unclear how the down regulation of class II expression relates to these differentiation-like phenomena. In our hands, PMA-induced differentiation of U937 cells resulted in enhanced expression of LFA-1- $\alpha$ and $-\beta$, and CD1 $1 \mathrm{~b}$ and CD1 1c antigens, but no effect on class II expression was observed (data not shown). Hence, the differentiation-like effects and the down regulation of class II antigens by HIV infection possibly are independent events. Our results in vitro parallel the previously reported finding in vivo that class II expression is decreased on APC in HIV-infected individuals $(11,12)$. In agreement with the findings of Heagy et al. (11) with monocytes from AIDS patients, we showed that r-interferon- $\gamma$ was able to enhance class II expression on infected U937 cells. The finding that HIV can be isolated from monocytes/macrophages from sero-positive persons (1), together with our data, suggests that decreased classII expression on APC in HIV-infected individuals may be directly caused by HIV infection.

As to the mechanism of class II down regulation by HIV, a parallel might be drawn to HLA class I down regulation of virustransformed rodent cells (adenovirus 12 and SV40) $(34,35)$. The down regulation of class I molecules is brought about by products of the adenovirus 12 Ela-gene region (34). It has been reported that the HIV TAT-III-gene product stimulates, by a transactivation mechanism, viral gene expression $(36,37)$. Moreover, induction of cellular Interleukin 2 receptor-gene expression by the transacting $p 40^{x}$ protein of HTLV-1 was recently reported by Inoue et al. (38). Hence, HIV-gene products possibly may directly or indirectly alter regulation of expression of cellular genes, thereby inducing phenotypic and functional changes in the infected cells.

It is well established that the amount of class II expressed on APC is directly correlated with the functional properties of APC in the induction of antigen-specific T-helper responses (39). The immunological abnormalities observed in HIV-infected individuals with normal $\mathrm{CD} 4^{+} \mathrm{T}$ cell numbers may, therefore, be explained by HIV infection of antigen-presenting cells, resulting in impaired APC functions.

\section{Acknowledgment}

Supported by a grant from the Netherlands Foundation for Preventive Medicine (28-1097).

\section{References}

1. Ho, D. D., T. R. Rota, and M. S. Hirsch. 1986. Infection of monocytes/macrophages by human T lymphotropic virus type III. J. Clin. Invest. 77:1712-1715.

2. Gartner, S., P. Markovits, D. M. Markovitz, M. H. Kaplan, R. C. Gallo, and M. Popovic. 1986. The role of mononuclear phagocytes in HTLV-III/LAV infection. Science (Wash. DC). 233:215-219.

3. Levy, J. A., J. Shimabukuro, T. McHugh, C. Casavant, D. Stites, and L. Oshiro. 1985. AIDS-associated retroviruses (ARV) can productively infect other cells besides human T-helper cells. Virology. 147:441448.

4. Sodroski, J., W. C. Goh, C. Rosen, K. Campbell, and W. A. Haseltine. 1986. Role of the HTLV-III/LAV envelope in syncitium formation and cytopathicity. Nature (Lond.). 322:470-474.

5. Lifson, J. D., M. B. Feinberg, G. R. Reyes, L. Rabin, B. Banapour, S. Chakrabarti, B. Mass, F. Wong-Staal, K. S. Steiner, and E. G. Engleman. 1986. Induction of CD4-dependent cell fusion by the HTLV-III/ LAV envelope glycoproteins. Nature (Lond.). 323:725-728.

6. Gendelman, H. B., O. Narayan, S. Molineaux, J. E. Clements, and Z. Ghotbi. 1985. Slow persistent replication of lentivirus: role of tissue macrophages and macrophage precursors in bone marrow. Proc. Natl. Acad. Sci. USA. 82:7086-7090.

7. Sonigo, P., M. Alizan, K. Starkus, D. Klatzmann, S. Cole, O. Damos, E. Retzel, P. Tiollais, A. Haase, and S. Wain-Hobson. 1985. Nucleotide sequence of the visna lentivirus: relationship to the AIDS virus. Cell. 42:369-382.

8. Lane, H. C., J. M. Depper, W. C. Greene, G. Whalen, T. A. Waldmann, and A. S. Fauci. 1985. Qualitative analysis of immune function in patients with acquired immunodeficiency syndrome. $N$. Engl. J. Med. 313:79-84.

9. Smith, P. S., K. Ohura, H. Masur, H. C. Lane, A. S. Fauci, and S. M. Wahl. 1984. Monocyte function in the acquired immune deficiency syndrome: defective chemotaxis. J. Clin. Invest. 74:2121-2128.

10. Prince, H., D. Moody, B. Shubin, and J. L. Fahey. 1985. Defective monocyte function in acquired immune deficiency syndrome (AIDS): evidence from a monocyte-dependent T-cell-proliferative system. J. Clin. Immunol. 5:21-25.

11. Heagy, W., V. E. Kelley, T. B. Strom, K. Mayer, H. M. Shapiro, R. Mandel, and R. Finberg. 1984. Decreased expression of human classII antigens on monocytes from patients with acquired immune deficiency syndrome. Increased expression with Interferon- $\gamma . J$. Clin. Invest. 74: 2089-2096.

12. Belsito, D. V., M. R. Sanchez, R. L. Baer, F. Valentine, and G. J. Thorbecke. 1984. Reduced Langerhans' cell Ia antigen and ATPase activity in patients with the acquired immunodeficiency syndrome. $N$. Engl. J. Med. 310:1279-1282.

13. Gallo, R. C., S. Z. Salahuddin, M. Popovic, G. M. Shearer, M. Kaplan, B. P. Haynes, T. J. Palker, R. Redfield, J. Oleski, B. Safai, G. White, P. Forster, and P. D. Markham. 1984. Frequent detection and isolation of cytopathic retroviruses (HTLV-III) from patients with AIDS and at risk of AIDS. Science (Wash. DC). 224:500-503.

14. Tersmette, M., R. E. Y. de Goede, J. Over, E. de Jonge, H. Radema, C. J. Lucas, J. G. Huisman, and F. Miedema. 1986. Thermal inactivation of human immunodeficiency virus (HIV) in lyophilized blood products evaluated by IDso titrations. Vox Sang. 51:239-243.

15. Popovic, M., M. G. Sarngadharan, E. Read, and R. C. Gallo. 1984. Detection, isolation and continuous production of cytopathic retroviruses (HTLV-III) from patients with AIDS and pre-AIDS. Science (Wash. DC). 224:497-500.

16. Goudsmit, J., F. Miedema, M. J. G. J. Wijngaarden-du Bois, J. van der Noordaa, and C. J. M. Melief. 1985. Immunoglobulin subclasses 
of antibodies to human T-cell leukemia/lymphoma virus-I-associated antigens in AIDS and lymphadenopathy syndrome. J. Virol. 53:287291.

17. Yam, L. T., C. Y. Li, and W. H. Crosby. 1971. Cytochemical identification of monocytes and granulocytes. Am. J. Clin. Pathol. 35: 283-290.

18. Tetteroo, P. A. T., A. Mulder, P. M. Lansdorp, H. Zola, D. A. Baker, F. J. Visser, and A. E. G. Kr. von dem Borne. 1984. Myeloidassociated antigen 3- $\alpha$-fucosyl- $\mathrm{N}$-acetyl-lactosamine (FAL): location on different membrane glycoproteins and masking upon monocyte differentiation. Eur. J. Immunol. 14:1089-1095.

19. Majdic, O., P. Bettelheim, H. Stockinger, W. Aberer, K. Liszka, D. Lutz, and W. Knapp. 1984. M2, a novel myelomonocytic cell-surface antigen and its distribution on leukemic cells. Int. J. Cancer. 33:617623.

20. Tetteroo, P. A. T., E. van der Schoot, F. J. Visser, M. J. E. Bos, and A. E. G. Kr. von dem Borne. 1986. Three different types of $\mathrm{Fc} \gamma$ receptor on human leukocytes defined by workshop antibodies: $F c \gamma R_{\text {low }}$ of neutrophils, Fc $\gamma R_{\text {low }}$ of $\mathrm{K} / \mathrm{NK}$ lymphocytes and Fc $\gamma \mathrm{RII}$. In Proceedings of the Third International Workshop on Human Leucocyte Differentiation Antigens, Oxford. In press.

21. Brodsky, F. M., and P. Parham. 1982. Monomorphic anti-HLAA, B, C monoclonal antibodies detecting molecular subunits and combinational determinants. J. Immunol. 128:129-135.

22. Shaw, S., M. Sanchez-Perez, and R. DeMars. 1984. Analysis of DP-region products by $\mathrm{T}$ cells and monoclonal antibodies: blocking of DP-specific proliferation and cell-mediated cytotoxicity. In Histocompatibility Testing, Munksgaard, Copenhagen. 465-468.

23. Breard, J., E. L. Reinherz, P. C. Kung, G. Goldstein, and S. F. Schlossman. 1980. A monoclonal antibody reactive with human peripheral blood monocytes. J. Immunol. 124:1943-1948.

24. Lanier, L. L., M. A. Arnaout, R. Schwarting, N. L. Warner, and G. D. Ross. 1985. p150/95, third member of the LFA-1/CR3 polypeptide family identified by anti-Leu M5 monoclonal antibody. Eur. J. Immunol. 15:713-718.

25. Miedema, F., P. A. T. Tetteroo, W. G. Hesselink, G. Werner, H. Spits, and C. J. M. Melief. 1984. Both Fc receptors and lymphocytefunction-associated antigen 1 are required for the effector-cell function in antibody-dependent cellular cytotoxicity (K-cell activity) mediated by T $\gamma$ cells. Eur. J. Immunol. 14:518-523.

26. Sanchez-Madrid, F., J. A. Nagy, E. Robbins, P. Simon, and T. A. Springer. 1983. A human leukocyte differentiation antigen family with distinct $\alpha$-subunits and a common $\beta$-subunit: the lymphocyte function-associated antigen (LFA-1), the C3bi-complement receptor (OKM1/ MAC-1), and the p150,95 molecule. J. Exp. Med. 158:1785-1803.

27. Keizer, G. D., J. Borst, C. G. Figdor, H. Spits, F. Miedema, C. Terhorst, and J. E. de Vries. 1985. Biochemical and functional charac- teristics of the human leukocyte membrane antigen family LFA-1, Mo1 and p150,95. Eur. J. Immunol. 15:1142-1147.

28. Rothlein, R., M. L. Dustin, S. D. Marlin, and T. A. Springer. 1986. A human intercellular adhesion molecule (ICAM-1) distinct from LFA-1. J. Immunol. 137:1270-1274.

29. Koeffler, H. P., J. Ranyard, L. Yelton, R. Billing, and R. Bohman. 1984. $\gamma$-Interferon induces expression of the HLA-D antigens on normal and leukemic human myeloid cells. Proc. Natl. Acad. Sci. USA. 81: 4080-4084.

30. Capobianchi, M. R., F. Ameglio, R. Tosi, and A. Dole. 1985. Differences in the expression and release of DR, BR and DQ molecules in human cells treated with recombinant interferon- $\gamma$. Comparison to other interferons. Hum. Immunol. 13:1-11.

31. Springer, T. A., and D. C. Anderson. 1986. The importance of the MAC-1, LFA-1 glycoprotein family in monocyte and granulocyte adherence, chemotaxis and migration into inflammatory sites: insights from an experiment of nature. In Biochemistry of Macrophages. (CIBA Foundation Symposium 118). Pitman, London, 102-126.

32. Fleit, H. B., S. D. Wright, C. J. Durie, J. E. Valinsky, and J. C. Unkeless. 1984. Ontogeny of $\mathrm{Fc}$ receptors and complement receptor during human myeloid differentiation. J. Clin. Invest. 73:516-525.

33. Minta, J. O., and L. Pambrun. 1985. In-vitro induction of cytologic and functional differentiation of the immature human monocytelike cell-line U937 with phorbol-myristate acetate. Am. J. Pathol. 119: 111-126.

34. Schrier, P. I., R. Bernards, R. T. M. J. Vaessen, A. Houweling, and A. J. van der Eb. 1983. Expression of class-I major histocompatibility antigens switched off by highly oncogenic adenovirus 12 in transformed rat cells. Nature (Lond.). 305:771-775.

35. Bernards, R., P. I. Schrier, A. Houweling, J. L. Bos, A. J. van der Eb, M. Zijlstra, and C. J. M. Melief. 1983. Tumorigenicity of cells transformed by adenovirus type 12 by evasion of T-cell immunity. Nature (Lond.). 305:776-779.

36. Rosen, C. A., J. G. Sodroski, W. C. Goh, A. I. Dayton, J. Lippke, and W. A. Haseltine. 1986. Post-transcriptional regulation accounts for the trans-activation of the human T-lymphotropic virus type III. Nature (Lond.). 319:555-559.

37. Dayton, A. I., J. G. Sodroski, C. A. Rosen, W. C. Goh, and W. A. Haseltine. 1986. The trans-activator gene of the human T-cell lymphotropic virus type III is required for replication. Cell. 44:941-947.

38. Inoue, J., M. Seiki, T. Taniguchi, S. Tsuru, and M. Yoshida. 1986. Induction of Interleukin-2 receptor gene expression by $p 40^{x}$ encoded by human T-cell leukemia virus type 1. EMBO J. 5:2883-2888.

39. Matis, L. A., P. J. Jones, D. B. Murphy, S. M. Hedrick, E. A. Lerner, C. A. Janeway Jr., J. M. McNicolas, and R. H. Schwartz. 1982. Immune response gene function correlates with the expression of an Ia antigen. J. Exp. Med. 155:508-523. 